DOI: $10.22363 / 2312-9182-2018-22-4-717-748$

\title{
Anna Wierzbicka, language, culture and communication
}

\author{
Anna Gladkova ${ }^{1,2}$ and Tatiana Larina ${ }^{3}$ \\ ${ }^{1}$ Monash University \\ Clayton Campus, Melbourne, VIC 3800, Australia \\ ${ }^{2}$ Australian National University \\ Canberra, ACT 0200, Australia \\ ${ }^{3}$ Peoples' Friendship University of Russia (RUDN University) \\ 6, Miklukho-Maklaya, 117198, Moscow, Russia
}

\section{Анна Вежбицкая: язык, культура, коммуникация}

\author{
А.Н. Гладкова ${ }^{1,2}$, Т.В. Ларина ${ }^{2}$ \\ ${ }^{1}$ Monash University \\ Clayton Campus, Melbourne, VIC 3800, Australia \\ ${ }^{2}$ Australian National University \\ Canberra, ACT 0200, Australia \\ ${ }^{3}$ Российский университет дружбы народов (РУДН) \\ Москва 117198, Миклухо-Маклая, 6
}

\begin{abstract}
The Introductory article to the second part of the Special Issue dedicated to Anna Wierzbicka's anniversary focuses on her research in the domain of language and culture interchange. It overviews the fundamental concepts of Wierzbicka's research program, those of cultural keywords and cultural scripts within the cultural semantics and ethnopragmatics paradigm. As is the case with other Wierzbicka's linguistic studies, the analysis involves representation of meaning in terms of universal human concepts of the Natural Semantic Metalanguage (NSM). The article also discusses the concept of Minimal Language as a recent development in the NSM programme and associated research into various fields.
\end{abstract}

Keywords: Anna Wierzbicka, cultural keywords, cultural scripts, Natural Semantic Metalanguage, cultural semantics, ethnopragmatics, Minimal Language

\section{INTRODUCTION}

This article introduces the second part of the Special Issue of the Russian Journal of Linguistics dedicated to Anna Wierzbicka's anniversary. In Gladkova and Larina (2018) we outlined the key points of the Natural Semantic Metalanguage approach developed by Anna Wierzbicka as an instrument of semantic analysis. In this article we will focus on Wierzbicka's research primarily aimed at the analysis of cultural 
aspects of meaning and the notions of cultural keywords and cultural scripts. We will then overview work by Wierzbicka, her colleagues and followers offering various applications of the approach. Consequently, the articles in this volume primarily engage with issues relating to cultural semantic and pragmatic analysis, interface of language, culture and communication.

\section{CULTURAL ASPECTS OF MEANING IN WIERZBICKA'S RESEARCH PROGRAMME}

\subsection{Cultural keywords}

Wierzbicka's search for lexical universals in language went hand in hand with the agenda to identify and describe culture-specific elements of meaning. This kind of empirical research aimed at identifying cultural influence in language led to the understanding that culture manifests itself in language in a variety of ways. "Cultural ideas" penetrate language and get encoded in the meanings of lexemes, morphemes and grammatical constructions, as well as the level of speech practices. Cultural keywords are an illustration of such cultural meanings (Wierzbicka 1997a). Wierzbicka (1997a: 15-16) defines cultural keywords as "words which are particularly important and revealing in a given culture." Cultural keywords are salient in the collective psyche of a society and their meanings resonate with meanings of other linguistic units and cultural practices. These words commonly denote values, attitudes, speech acts, social categories, among others.

Wierzbicka (1997a: 16) argues that "there is no finite set of such words in a language, and there is no 'objective discovery procedure' for identifying them. To show that a particular word is of special importance in a given culture, one has to make a case for it." According to Wierzbicka, a word might be claimed to be a keyword if it meets the following criteria: (1) it has a relatively high frequency in the semantic domain it belongs to, (2) it is at the centre of a phraseological cluster and (3) it might be part of common sayings or expressions.

Wierzbicka (1997a: 16) sums up the procedure of identifying cultural key words as follows:

But the question is not how to "prove" whether or not a particular word is one of the culture's key words, but rather to be able to say something significant and revealing about that culture by undertaking an in-depth study of some of them. If our choice of words to focus on is not "inspired" we will simply not be able to demonstrate anything of interest.

Therefore, there is no strict rule about the part of speech or lexical domain that a cultural keyword can belong to. In fact, it can be represented by almost any part of speech as long as it is shown to be revealing of important cultural attitudes. Observations suggest that most commonly such words are from domains of emotions, values, attitudes, social categories, among others.

Some of Wierzbicka's discoveries of cultural keywords in Anglo English include privacy, personal autonomy, fairness, mind, reasonable, sense, evidence, experience, among others (Wierzbicka 2006a, b, 2010a). In Australian English she identifies bloody, bullshit, whinge, dob in as keywords (Wierzbicka 1997a, 2002b). Wierzbicka is also 
widely known for identifying Russian keywords $d u \check{s} a$ 'soul', sud'ba 'fate', toska 'yearning', iskrennost' 'sincerity', pravda 'truth', obščenie 'communication' and avos' 'maybe' (Wierzbicka 1990, 2002a, 2010b, see also Šmelev 2002, Zaliznjak, Levontina, Šmelev 2005, 2012, Gladkova 2010b, among others). In Polish, Wierzbicka has described as keywords przykro 'unpleasantly', rodzina 'family', wolność 'freedom', among others (Wierzbicka 1997a, 2001b).

Importantly, the principles of semantic analysis advocated and practiced by Wierzbicka also apply to the analysis of cultural keywords. A thorough semantic investigation leads to the proposal of a semantic explication of the keyword in simple universal concepts as they are identified in the Natural Semantic Metalanguage (NSM) developed by Anna Wierzbicka and Cliff Goddard (for an overview of NSM see Gladkova and Larina 2018, Goddard 2010a). NSM is a mini-language that lies at the core of every language. The universal properties of the primes guarantee their translatability into all languages. Thus, when culture-specific meanings are formulated using primes, they can be understood by speakers of all languages of the world (Goddard and Wierzbicka eds. 1994, 2002).

We will quote the semantic explication of the Russian keyword sud'ba proposed by Wierzbicka (2010b:13):

sud'ba (someone's sud'ba)
a. something
b. people can say what this something is with the word sud'ba
c. people can say something with this word about someone when they think like this:
d. "people live for some time
e. when someone lives, many things happen to this someone during this time not because this someone wants it
f. at the same time, if this someone very much wants something to happen during this time, often these things don't happen
g. this someone can't know about many things that these things will happen to this someone during this time before they happen
h. some of these things can be good things
i. many of these things can be bad things
j. it can't be not like this
k. all these things are parts of one thing"
I. many people think about it like this:
$\mathrm{m}$. "all these things happen to people in this way because someone wants it
$\mathrm{n}$. this someone is not someone like people
o. this someone is someone above people"

Wierzbicka's ideas about cultural keywords have received a lot of attention in the literature. Her methodology and approach have been successfully applied by researchers in various languages and cultures within the NSM framework. Goddard and Cramer (2017) describe laid back and irreverent as keywords of Australian English. Bromhead (2009) analyses English truth and faith in a historical perspective. Travis (2006) posits calor humano 'human warmth' as a cultural keyword of Spanish. Levisen names hygge 'pleasant togetherness', tryghed 'security' and janteloven 'the Jante law' cultural keywords of Danish (Levisen 2012). For Chinese, such concepts were shown to be shengren 'stranger' and shuren 'an old acquaintance' by Ye (2004). In Korean, Yoon (2004) 
claims noin 'respected elderly people' to be a cultural keyword. Peeters proposed to treat French râler 'grumble' (Peeters 2013), on va s'arranger 'we will arrange' and on s'arrangera 'we will manage' (Peeters 2014) as cultural keywords'. (See also Levisen and Waters 2018).

\subsection{The cultural scripts approach}

Another important development of Wierzbicka's approach to linguistic analysis in the area of pragmatics (or ethnopragmatics as its branch) is known as the theory of cultural scripts (e.g., Wierzbicka 2003/1991, Goddard and Wierzbicka eds. 2004, Goddard 2006). Goddard and Wierzbicka (2004: 153) refer to cultural scripts as a "powerful new technique for articulating cultural norms, values, and practices in terms which are clear, precise, and accessible to cultural insiders and to cultural outsiders alike". The cultural scripts approach relies on the Natural Semantic Metalanguage to formulate cultural norms, ideas and understandings that are shared by speakers of a language and that are reflected in that language. It is consistent with the idea that language and culture are interconnected and that certain linguistic practices are reflective of culturally shared understandings. It is often possible to find a semantic correlation between dominant cultural scripts and cultural keywords (see, for example, Wierzbicka 2002a, 2006b, among others).

The types of linguistic data that are most revealing when it comes to identifying cultural scripts are conversational routines, common sayings and proverbs, frequent collocations and varieties of formulaic and semi-formulaic speech. Discourse particles, interjections and terms of address and reference also commonly embody cultural attitudes. They can reflect communicative practices and capture specificity of a "communicative style" (Goddard 2006). Evidence for cultural scripts can also come from data acquired from bilinguals. Wierzbicka has actively relied on such data and her own autobiographical narratives are extremely illuminating (Wierzbicka 1997b, 2007, Besemeres and Wierzbicka eds. 2007).

The use of cultural scripts as a technique of formulating cultural norms has a number of advantages. Firstly, cultural scripts are capable of representing the cultural insiders' perspective. Secondly, the use of simple and intelligible concepts creates a possibility for the scripts to be verified by cultural insiders. Thirdly, they are free from an ethnocentric bias which is present in some cultural research.

The use of the same inventory of semantic primes in constructing explications and cultural scripts allows one to show explicitly the relation between the meaning of a word and cultural ideas and beliefs that it is related to. At the same time cultural scripts differ from semantic explications. While semantic explications represent meaning of a particular concept, cultural scripts reflect broader cultural norms. These norms concern ways of thinking, speaking and behaving that are salient in a particular culture. As it has been mentioned, cultural scripts have a linguistic grounding in cultural key words, proverbs and common sayings, terms of address, phraseological patterns, among others (Goddard 2006), but they formulate ideas that are broader than the meaning of one word or concept.

${ }^{1}$ A full list of the NSM bibliography is available on the NSM Homepage and NSM-APPROACH.NET. 
We will illustrate the application of the cultural scripts approach with several Anglo English cultural scripts proposed by Anna Wierzbicka. Wierzbicka (2006a) relates a common use of "whimperatives" for wording requests, the cultural rules of using thank you and the avoidance of imperatives and phrases like you must in suggestions in English, with the prevalence of the value of 'personal autonomy'. She argues that the idea that 'it is not good to impose and force other people to do certain things' is a cultural idea shared by English speakers and that it finds its realisation in language and communication. Wierzbicka (2006a: 52) formulates this cultural rule as follows:

[people think like this:]

no one can say to another person:

"I want you to do this

you have to do it because of this"

[people think like this:]

no one can say to another person:

"I don't want you to do this

you can't do it because of this"

(Wierzbicka 2006a: 52)

She explains these scripts as follows: "These scripts don't say that people can do anything they want to do or that there can be no rules legitimately preventing people from doing what they want to do. Rather, they say that it cannot be another person's expression of will that prevents me from doing what I want to do or forces me to do what I don't want to do" (Wierzbicka 2006a: 52).

Goddard and Wierzbicka (2004: 156) formulate a related cultural rule of valuing personal autonomy in Anglo society as follows:

[people think like this:]

when a person is doing something

it is good if this person can think about it like this:

'I am doing this because I want to do it

not because someone else wants me to do it'

This script formulates an Anglo cultural norm which is closely associated with the English cultural key words freedom and free (see also Wierzbicka 1997a, Larina, Ozyumenko 2017).

Wierzbicka further demonstrates that the value of personal autonomy in English is closely related to another cultural value, namely the inclination not to put undue pressure on other people, and that both are reflected in English (Wierzbicka 2006a, b). She notes that the expressions to put pressure and to act under pressure in contemporary English are highly revealing in this regard. Interestingly, they did not occur in Shakespeare's language, which suggests modern salience of the value of 'nonimposition'. The expression to put pressure and its negative cultural connotation

2 Whimperative (or wh-imperative) is a command or request which is worded as a question (e.g. Would you mind washing it out?, Could you just turn it down a bit?). The term consists of wh-, which stands for an interrogative word, and imperative. 
highlight the idea that there exists a cultural prohibition on imposing one's will on other people and expecting them to act in accord with the will of other people. A related cultural script is formulated by Wierzbicka (2006a: 52) as follows:

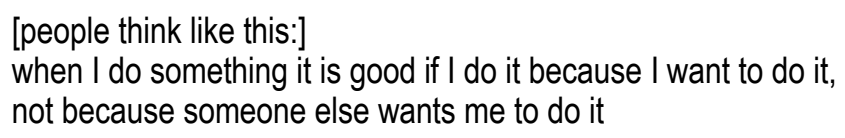

(Wierzbicka 2006a: 52)

Importantly, these scripts proposed by Wierzbicka might not apply in all varieties of English due to differing cultural norms. In this regard, Wong (2004) argues that although English is widely spoken in Singapore, conversational strategies of Singapore English do not fully overlap with those of Anglo English. In particular, Wong shows that Singapore English lacks cultural scripts of Anglo-style personal autonomy in the style of scripts quoted above. He formulates a relevant cultural script for Singapore English as follows (Wong 2004: 239):

[people think like this:]

when I say to someone about something "I want you to do it"

I can think about it like this:

if this person can do it, this person will do it

[people think like this:]

when someone says to me about something "I want you to do it"

if I can do it, it is good if I do it

The cultural scripts formulated by Wierzbicka (2006a) and Wong (2004) refer to cultural rules relating to making requests or asking people to do something in two different cultures. The use of the same set of simple and universal words makes the cultural differences between these rules transparent and easy to demonstrate.

Using the cultural scripts approach Wierzbicka has described numerous communicative practices in different languages and cultures relating to different speech acts, speech genres and discourses, including religious discourse (see Wierzbicka 2003/1991, 2001a, 2002, among others). She has also demonstrated that cultural scripts can be applied to capture the display rules of emotions, their functions in communication and cultural specificity (Alba-Juez, Larina 2018, Ionova, Shakhovsky this issue, Wierzbicka 1999a, b, 2001b, 2018c).

Wierzbicka's cultural scripts and simple formulae of what is considered good and bad in a given culture have a great explanatory potential and can reduce negative stereotyping. For example, the following cultural scripts (Wierzbicka 2002a) represent Russian cultural norms relating to iskrennost 'sincerity', the meaning of which differs significantly from its English translation equivalent (Gladkova 2017, Wierzbicka 2002a):

it is good if a person wants to say to other people what this person thinks (feels)

it is bad if a person says to other people that this person thinks (feels) something if it is not true it is good if a person wants other people to know what this person thinks (feels)

These cultural rules explain salient characteristics of Russian communicative style which are often perceived as excessive openness, lack of tact, straightforwardness, dislike for formal communication and uncontrolled display of emotions from the point of view of representatives of many Western cultures (for details, see Larina 2009, 2013). 
The cultural scripts approach has been successfully applied by Wierzbicka's colleagues to various languages and language varieties, such as Australian English and other varieties of English (Goddard 2012, 2015, 2016), African languages (Ameka 2006), Chinese (Ye 2004, 2013), Korean (Yoon 2004), Singapore English (Wong 2004, 2014), Russian (Gladkova 2010a, b, 2013a, b, 2017), Japanese (Asano-Cavanagh 2016, Hasada 2006), Danish (Levisen 2012, 2013), French (Peeters 2013, 2014), Italian (Farese 2018), among others.

Wierzbicka's approach to studying language through the prism of culture has inspired research of numerous scholars in Russia. In particular, there has been long and fruitful collaboration between Anna Wierzbicka and the Moscow School of Semantics under the leadership of Jurij Apresjan (e.g., Apresjan 1995, 2006, 2014, V. Apresjan 2018). In addition, numerous studies by the Moscow group of cultural semantics aimed at the reconstruction of the Russian linguistic worldview demonstrate shared views on language, culture and their interface (e.g., Zalizniak 2013, Zalizniak, Levontina, Shmelev 2005, 2012; Zalizniak, Paducheva 2018, Shmelev 2002, 2018, among others). Wierzbicka's work has also influenced research of many Russian scholars in the areas of cultural linguistics (Bogdanova 2015, 2017; Dobrichev, Kozlova, Pshenkina 2013; Zykova 2017; Ivanova 2003, 2004, 2016, Ivanova, Chanysheva 2010; Karasik 2002, 2009, 2015, 2016; Kovshova 2013; Krasnykh 2002; Larina, Mustajoki, Protassova 2017; Larina, Ozyumenko, Kurteš 2017), anthropological linguistics (Karasik 2010), emotiology (Shakhovsky 2008, 2010, 2015, 2018; Panchenko, Volkova 2018), ethnogrammar (Kozlova 2009), communicative ethnostylistics (Larina 2007, 2009, 2015), intercultural communication (Klyukanov, Leontovich 2017, Leontovich 2005, 2007; Larina 2013, 2017; Privalova 2005, Ter-Minasova 2000), among others ${ }^{3}$.

Wierzbicka's theory of cultural key words and cultural scripts has a significant potential of being used in language teaching and learning. Cultural scripts can help students understand the relationship between language and culture and develop intercultural communicative competence. Cultural scripts can develop leaners' understanding of why in different societies people speak differently and assist educators in explaining the pragmatic rules of language use with ease and clarity. Teaching language and culture through key words and cultural scripts can help students acquire a different cultural logic from the insider's perspective and become reflective language learners and critical thinkers (e.g., Goddard 2010b, Goddard and Wierzbicka 2007, Kurtes et al. 2017, Ozyumenko, Larina 2018, Wong 2018).

\section{FURTHER DEVELOPMENTS AND APPLICATIONS OF NSM: MINIMAL LANGUAGE}

In her 2014 book Imprisoned in English: The Hazards Of English As A Default Language (chapter 14) Wierzbicka introduces the concept of Minimal English, that is a "mini English", which can provide "a common auxiliary inter-language for speakers of different languages". This idea is further developed in Goddard and Wierzbicka (2018)

${ }^{3}$ In this overview we do not include Anna Wierzbicka's influence on Russian theoretical linguistics. 
in the form of Minimal Language (see also Goddard 2018, Wierzbicka 2018b). This interlanguage is based on the results of the linguistic research put into the development of the NSM. It includes universal concepts along more complex vocabulary, such as semantic molecules. It is expected that, as it is the case with NSM, the versions of this metalanguage can be developed for other languages (e.g., Minimal Russian, Minimal Spanish, etc.).

Goddard (ed. 2018) is an edited volume which contains examples of application of Minimal English in various fields. Wierzbicka is an active developer of the idea of Minimal English and in this book she exemplifies application of Minimal English in teaching science to children and wording the principles of the Charter of Global Ethic (Wierzbicka 2018a, b).

Anna Wierzbicka demonstrates the power of Minimal Language in her new book W co wierza chrześcijanie? Opowieści o Bogu i o ludziach (What Christians Believe: The Story of God and People) published in 2017 by Znak in Cracow, Poland, in Polish. An expanded English version is to be published by Oxford University Press in 2019 (Wierzbicka in press). The book retells and re-thinks the basics of Christian faith in simple words and sentences which can be understood by anyone and which are cross-translatable into any language. The book is a semantic and theological experiment, and at the same time, it is an experiment in cross-cultural communication through a minimal language. Minimal Polish and Minimal English match, word for word and phrase by phrase.

The Minimal English has gained momentum across various disciplines and there are several studies conducted by Wierzbicka's colleagues in which Minimal English is successfully implemented in fields like narrative medicine (Peeters and Marini 2018), disability and mental health issues (Jordan 2017), diplomacy (Maley 2018; Farrelly and Wesley 2018), human rights discourse (Mooney 2018), among others.

\section{ARTICLES IN THIS ISSUE}

The first author of the issue is Jerzy Bartminsky (Lublin, Poland). He is well known to the Russian reader due to his book Yazykovoy obraz mira: ocherki po etnolingvistike (Language Image of the World: Essays on Ethnolinguistics) (Bartminsky 2005). Wierzbicka has long-standing cooperation with the community of linguists centered around the journal Ethnolinguistics published in Lublin and Maria Curie-Skłodowska University. In his article, Jerzy Bartminski demonstrates similarities between Wierzbicka's and Lublin ethnolinguists' approaches to language, their opposition to taxonomic approaches to the study of meaning and adoption of the subjective reconstruction principle, which derives from Wilhelm Humboldt's philosophy of language. Both scientific schools proceed from the fact that it is necessary to study the meaning of words in the context of social life, history and culture. The author focuses on the concept of cognitive definition, discusses its genesis, principles of construction and the most important ideas. Although the concept itself was created as an extension of the research of the language of folklore, independently of Anna Wierzbicka's works and her method of the Natural Semantic Metalanguage, the author traces clear parallels between them, paying attention to some differences as well. Using the example of the concept of HOME/HOUSE, the article considers new perspectives of the use of cognitive definitions in comparative studies 
Anna Zalizniak (Moscow, Russia) presents in her article the Catalogue of sematic shifts (CSSh) and sets out its current state. The main notions of this framework are a semantic shift, which is understood as a relation of cognitive proximity between two linguistic meanings, and a realization of a semantic shift. The author states that the typology of semantic shifts occupies a position at the crossroad of semantic, lexical and grammatical typologies, however, the domain of CSSh does not coincide with any of them. She convincingly demonstrates that this framework is a tool for identifying and describing semantic shifts reproduced in the languages in the form of synchronous polysemy and/or diachronic semantic evolution. The article outlines the prospects for research and the scope of its possible results. It notes that linguistic data contained in the Database of Semantic Shifts can be used in all these areas, in order to provide semantic plausibility criteria for linguistic reconstruction, to act as empirical evidence for cognitive mechanisms of linguistic conceptualization, to aid in identifying specific features of the semantic system of a given language or group of languages.

At the centre of attention of the article by Alain Polguère (Nancy, France) is the notion of copolysemy, which is closely associated with regular polysemy. The author adopts an approach where polysemy is defined as a property of vocables (roughly, entries in dictionary word lists) to regroup several word senses, while monosemy being the opposite property. Polysemy is the consequence of a more basic fact: the relation that holds between lexical units grouped within the same vocable. This relation is termed copolysemy. The article presents the current results of an exploration of copolysemy in French, which makes it possible to systematically retrieve patterns of copolysemy and achieve formal description of the polysemy structure of several thousand French vocables. The descriptive work is embedded in a large-scale lexicographic project, namely the construction of the French Lexical Network (fr-LN).

Svetlana Ivanova (St. Petersburg, Russia) and Zulfira Chanysheva (Ufa, Russia) analyse the cultural semantics of lexical units in political discourse through the prism of Anna Wierzbicka's views. Using the example of English lexical units such as whistleblower, kangaroo ticket, log cabin president, Camelot presidency, redneck, etc., the authors show how, along with the lexical meaning recorded in dictionaries, the lexemes are able to generate various cultural meanings in discourse. The analysis is based on different levels of organization of culture as a whole, taking into account the dynamics of cultural universe (Ivanova 2016). This approach makes it possible to identify those semantic stratifications in the meaning of the considered lexical units, which reflect the consolidation of new values in the society. The procedure of meaning interpretation makes it possible to single out core cultural practices and to reveal their dynamics. This approach could be of interest to linguists working in the field of cultural and interpretative semantics, cultural linguistics and discourse analysis.

Liudmila Bogdanova (Moscow, Russia) continues the theme of identifying evaluative meanings in language (see Bogdanova 2017), but this time on the material of grammar. Her article in this issue shows how the idea of semantic basis of grammar, created and developed by Anna Wierzbicka, has a continuation in the study of role and place of evaluative meanings in productive grammar of the Russian language. The author aims to identify evaluative meanings that are important for grammar and show how the subjective component of the meaning of a verb affects the way in which its actant 
positions are expressed. The article identifies the co-relation between intellectual and emotional evaluative characteristics of a verb, which have an output in the grammatical space of the language. The author demonstrates that evaluation (both positive and negative), which verbal semantics contains, affects the syntagmatic behavior of the verb selectively, requires additional efforts in establishing those semantic zones where the role of evaluative component in the grammatical formulation of actant position is the most significant. The author outlines further prospects for studying verb semantics, which make it possible to define a new perspective for disclosure of a culture specific worldview that could contribute to the development of comparative axiology.

Lyubov Kozlova (Barnaul, Russia), author of the monograph "Ethnocultural potential of the grammatical structure of language and its realization in a speaker's grammar" published in Russian (Kozlova 2009) develops the topic of ethnocultural potential of grammar. Her article relates to the field of ethnogrammar, which engages with the reconstruction of cultural specificity on the basis of grammatical analysis and the identification of culture specific semantic components in the grammar of a language. As the author rightly points out, it was Anna Wierzbicka who expressed the idea that lexicon, as well as grammar, embody concepts that are of particular importance for a certain language and culture. In her study the author analyses the category of voice in the English language from an ethnocultural perspective with the aim to elucidate ethnological factors which determine the choice of voice forms in various types of discourse. The author shows the evolution of views on the essence of the category of voice in the context of changing paradigms of scientific knowledge, presents the essence of voice relations viewed from the functional and cognitive-discursive points of view and attempts to elucidate ethnocultural factors which determine the choice of both categorical and noncategorial voice forms in various types of discourse.

Vladimir Karasik (Moscow, Russia), who is well known to the Russian linguistic community for his research in the field of interface of language and culture (Karasik 2002, 2009, 2010, 2016 among others), devotes his article to semiotic characteristics of comic texts construction. As the author rightly points out, since the desire to joke is universal, the humorous intention is less characterized by language and culture specific characteristics and depends mostly on individual characteristics of a person. However understanding the joke is woven into the general context of culture. The aim of the study is to analyse semantic, pragmatic and syntactic properties of jokes and to identify models of comic texts comprehension. Using Russian jokes as data, the article discusses models of laughter behavior, describes semantic and pragmatic mechanisms of comic texts, distinguishes two models of creating and understanding comic texts: the first one is dictal in its essence and is based on disagreement between the planes of reality as shown in the text, whereas the second one is modal and it reflects an incongruity between reality and the view of it. All theoretical positions are illustrated with linguistic examples that will certainly make the reader smile.

Vadim Dementiev (Saratov, Russia), discusses in his article specificity of Russian indirect communication. The author bases his research on the opposition of personality impersonality, which, in his opinion, is a language and speech category which covers most levels and spheres of the Russian language and speech. The article discusses a number of current processes of modern Russian speech. 
In this issue, we start a new rubric in our journal called "Lectures" with an invited lecture by Professor Alexander Zholkovsky (Los Angeles, USA) entitled "Listomania, or catalogue as technique (with examples from poetry and prose, classical and modern, Western and Russian)". It was presented by him at the University of California, Berkeley on March 31, 2014.

The issue finishes with two review articles on the topics that are in the focus of Anna Wierzbicka's research paradigm. Svetlana Ionova (Moscow, Russia) and Victor Shakhovsky (Volgograd, Russia) overview Anna Wierzbicka's approach to the study of emotions. Natalia Naidenova (Moscow, Russia) analyzes in her review article the research on the interface of language and religion in modern, mainly Russian, linguistics.

\section{CONCLUDING REMARKS}

This article attempted to summarise Anna Wierzbicka's contribution to linguistic analysis in the area of language and culture interface. It mainly focused on the concepts of cultural keywords and cultural scripts which have a broad theoretical and practical application in cross-cultural pragmatics, text and discourse analysis, intercultural communication, second and foreign language teaching, etc. It also overviewed recent developments in Wierzbicka's approach to linguistic analysis such as Minimal English. We must admit that this is a very brief overview with the aim of introducing the main concepts of the approach to Russian and international readers. The scope of Wierzbicka's oeuvre is vast and it would be impossible to represent it in this article. The diversity of her approach allows multiple interpretations (as articles of this volume vividly demonstrate) and different readers are often inspired by different aspects of her research.

Once again, we conclude with wishing Anna many more years of joy, happiness and creativity!

\section{ACKNOWLEDGMENTS}

We thank the authors of this issue for their articles and participation in the review process, as well as reviewers for their valuable comments and active participation in the preparation of the issue. We also thank journal readers for their feedback and comments on the first volume of our special issue. All errors remain ours.

\section{RU}

\section{1. ВВЕДЕНИЕ}

Данная статья открывает вторую часть специального выпуска журнала «Вестник РУДН. Серия: Лингвистика», посвященного юбилею Анны Вежбицкой. В статье предыдущего номера (Гладкова, Ларина 2018) мы рассмотрели ключевые положения концепции Естественного Семантического Метаязыка (ЕСM), разработанного А. Вежбицкой в качестве инструмента семантического анализа. В этой статье мы остановимся на специфике реализации научного подхода А. Вежбицкой, 
направленного в первую очередь на анализ культурных аспектов смысла, а именно - на ключевых словах языка и культуры и культурных скриптах. Затем мы рассмотрим различные применения данного подхода в трудах А. Вежбицкой, ее коллег и последователей и кратко представим авторов данного выпуска и их исследования. Таким образом, в данном номере в основном будут рассмотрены вопросы культурной семантики и прагматики и взаимодействия языка, культуры и коммуникации.

\section{2. КУЛЬТУРНЫЕ АСПЕКТЫ СМЫСЛА В ИССЛЕДОВАТЕЛЬСКОЙ ПАРАДИГМЕ АННЫ ВЕЖБИЦКОЙ}

\section{1. Ключевые слова языка и культуры}

Поиск А. Вежбицкой лексических универсалий в языке шел рука об руку с выявлением и описанием культурно-специфичных элементов смысла. Эмпирические исследования, направленные на изучение влияния культуры на язык, привели к пониманию того, что культура проявляется в языке различными способами. «Культурные идеи» проникают в язык и кодируются в значениях лексем, морфем и грамматических конструкций, а также проявляются на уровне речевых практик. Иллюстрацией таких культурных значений являются ключевые слова языка и культуры (см. [Wierzbicka 1997a, Вежбицкая 1999b, 2001c, 2011b]). А. Вежбицкая определяет их как слова, которые особенно важны для данной культуры (Wierzbicka 1997a: 15-16), они живут в коллективном сознании общества, и их значения тесно переплетаются со значениями других языковых единиц, а также с культурными практиками. Эти слова обычно называют ценности, отношения, речевые акты, социальные категории и др.

А. Вежбицкая утверждает, что «нет конечного набора таких слов в языке, как нет и объективной процедуры их идентификации. Чтобы утверждать, что то или иное слово имеет особое значение для данной культуры, нужно предоставить доказательства» (Wierzbicka 1997: 16) ${ }^{4}$. Согласно А. Вежбицкой, слово может считаться ключевым, если оно отвечает следующим критериям: (1) имеет относительно высокий уровень частотности в семантической области, к которой оно относится; (2) находится в центре фразеологического кластера и (3) может быть составной частью распространенных высказываний и выражений.

Обобщая процедуру определения ключевых слов, Вежбицкая (Wierzbicka 1997a: 16) подчеркивает: «Главный вопрос не в том, как „доказать“, является ли конкретное слово одним из ключевых слов культуры или нет, а в том, что мы можем узнать значимое о культуре, проведя его глубинный анализ. Если данное слово не может сказать нам ничего интересного о культуре, наш выбор оказался неудачным». При этом нет строгих критериев относительно того, к какой части речи или лексической области должно относиться ключевое слово. Оно может быть представлено практически любой частью речи, если дает нам важную культурную информацию. Наблюдения показывают, что чаще всего такие слова относятся к области эмоций, ценностей, отношений, социальных категорий и др.

\footnotetext{
4 Здесь и далее перевод наш. - А.Г., Т.Л.
} 
В англосаксонской лингвокультуре А. Вежбицкая выделяет и описывает следующие ключевые слова: privacy 'прибл. личное пространство', personal autonomy 'личная автономия/личная независимость', fairness 'справедливость', mind 'разум', reasonable 'прибл. разумный', sense 'смысл', evidence 'доказательство', experience 'опыт' и др. (Wierzbicka 2006a, b, 2010a). В австралийском английском она идентифицирует в качестве ключевых слова bloody 'проклятый', bullshit 'чушь/ ерунда', whinge 'хныкать', dob in 'доносить на кого-либо' (Wierzbicka 1997, 2002b). Среди ключевых слов русского языка и культуры А. Вежбицкая называет слова душа, судьба, тоска, а также искренность, правда, общение и авось (Wierzbicka 1990, 2002a, 2010b. См. также [Шмелев 2002, Зализняк, Левонтина, Шмелев 2005, 2012, Гладкова 2010b] и др.); к ключевым словам польского языка - слова przykro 'неприятно', rodzina ‘семья', wolność ‘свобода' (Wierzbicka 1997a, 2001b)5.

Важно отметить, что предложенные и используемые А. Вежбицкой принципы семантического анализа применимы также и к анализу ключевых слов культуры. Тщательное семантическое исследование показывает возможность толкования ключевого слова через простые универсальные понятия, представленные в разработанном Анной Вежбицкой и Клиффом Годдардом Естественном Семантическом Метаязыке (ЕСM) (общий обзор ЕСМ см. Gladkova, Larina 2018, Goddard 2010a). ECM - это мини-язык, лежащий в основе каждого языка. Универсальные свойства примитивов гарантируют их переводимость на любой язык. В результате, когда значения, специфичные для той или иной культуры, формулируются с использованием семантических примитивов, их могут понять представители любой культуры, говорящие на любом языке мира.

В качестве примера приведем предложенное А. Вежбицкой семантическое толкование русского ключевого слова судьба (Wierzbicka 2010b:13):

судьба (чья-то судьба)

a. что-то

b. люди могут сказать, что есть это что-то словом судьба

c. люди могут сказать что-то этим словом о ком-то, когда они думают так:

d. "люди живут некоторое время

е. когда кто-то живет, много вещей случается с этим кем-то за это время не потому, что этот кто-то этого хочет

f. в то же время, если этот кто-то очень хочет, чтобы что-то произошло за это время, часто эти вещи не происходят

g. этот кто-то не может знать о многих вещах, что эти вещи произойдут с этим кем-то за это время до того, как они произойдут

h. некоторые из этих вещей могут быть хорошими

i. многие из этих вещей могут быть плохими

j. не так быть не может

k. все эти вещи части одной вещи"

I. многие люди думают об этом так:

m. "все эти вещи происходят с людьми так, потому что кто-то это хочет

п. этот кто-то не как люди

о. этот кто-то над людьми"

5 Полный список публикаций по ЕCM доступен на NSM Homepage и NSM-APPROACH.NET. 
Идеям А. Вежбицкой о ключевых словах языка и культуры уделяется большое внимание в литературе. Ее методология и подход были успешно применены исследователями разных языков и культур. К. Годдард и Р. Крамер описывают laid back 'расслабленный' и irreverent 'непочтительный' как ключевые слова австралийского английского (Goddard, Cramer 2017). Х. Бромхед в исторической перспективе анализирует английские ключевые слова truth 'истина' и faith 'вера' (Bromhead 2009). К. Трэвис предлагает считать calor humano 'человеческое тепло’ культурным ключевым словом испанского языка (Travis 2006). К. Левисен называет hygge ‘уют', tryghed ‘безопасность' и janteloven 'закон Янте’ ключевыми словами датского языка (Levisen 2012). Среди ключевых слов китайского языка Йе выделяет shengren 'чужой' и shuren 'старый знакомый' (Yе 2004), в корейском Юн называет слово поin ‘уважаемые пожилые люди' (Yoon 2004). Во французском языке Б. Питерс предложил считать ключевыми словами rarler 'ворчать' (Peeters 2013), а также словосочетания on s'arrangera 'мы устроим' и on s'arrangera 'мы справимся' (Peeters 2014).

\section{2. ТЕОРИЯ КУЛЬТУРНЫХ СКРИПТОВ}

Важной разработкой А. Вежбицкой в области прагматики (или этнопрагматики как ее отрасли) является теория культурных скриптов (Wierzbicka 2003/1991, Goddard, Wierzbicka 2004, Goddard 2006 и др.). Культурные скрипты представляют собой инновационный способ формулирования культурных норм, ценностей и практик в терминах, которые ясны, точны и доступны как для представителей данной культуры, так и представителей других культур (Goddard, Wierzbicka 2004: 153). Данный подход основан на Естественном Семантическом Метаязыке, на котором и формулируются закрепленные в языке и разделяемые носителями данного языка культурные нормы и правила, что согласуется с идеей о взаимосвязи языка и культуры и о том, что определенные дискурсивные практики отражают особенности культуры. Между доминирующими культурными скриптами и ключевыми словами данной культуры можно часто найти семантическую корреляцию (см., например, Wierzbicka 2002a, 2006b, Вежбицкая 2011 и др.).

При описании культурных скриптов языковыми фактами, подтверждающими их значимость для данной культуры, могут служить повседневные речевые высказывания, пословицы и поговорки, формулы обращения, а также такие элементы дискурса, как, например, частицы и междометия, другими словами все, что фиксирует специфику «коммуникативного стиля» и отражает типичные коммуникативные практики. Большую роль играют также данные, полученные от билингвов. А. Вежбицкая активно использует такие свидетельства, и ее собственные автобиографические нарративы дают нам множество интересных иллюстраций (Wierzbicka 1997b, 2007, Besemeres, Wierzbicka eds. 2007).

Использование культурных скриптов как метода формулирования культурных норм имеет ряд преимуществ. Во-первых, культурные скрипты позволяют описать культурные нормы изнутри, т.е. они отражают точку зрения представителей 
данной культуры. Во-вторых, использование в скриптах простых и понятных понятий дает возможность носителям культуры верифицировать их подлинность. В-третьих, они свободны от этноцентристского уклона, который прослеживается во многих исследованиях.

Использование одного и того же набора семантических примитивов как в семантических толкованиях, так и культурных сценариях, позволяет показать явную связь между значением слова и представлениями и идеями культуры, с которыми оно связано. В то же время культурные скрипты отличаются от семантических толкований: семантические толкования описывают смысл конкретного концепта, культурные сценарии описывают связанные с ним культурные нормы в более широком плане. Эти нормы касаются того, как представители данной культуры мыслят, говорят и ведут себя. Культурные сценарии, как уже отмечалось, подтверждаются фактами языка и речи, в том числе ключевыми словами, пословицами, поговорками, формулами обращения, фразеологизмами (Goddard 2006), но они формулируют идеи, которые шире, чем смысл одного слова или понятия.

Мы проиллюстрируем концепцию культурных скриптов на примере нескольких скриптов англо-саксонской культуры, предложенных А. Вежбицкой. Она связывает такие коммуникативные особенности данной культуры, как избегание императивов и фраз типа you must, частое использование для выражения побуждения так называемых wh-императивов ${ }^{6}$, а также правила употребления thank you с культурной ценностью личной автономии (Wierzbicka 2006a). А. Вежбицкая утверждает, что идея о том, что «нехорошо оказывать давление на других и заставлять их что-то делать» - это культурная идея, разделяемая представителями англосаксонской культуры, которая реализуется в языке и коммуникации. Она формулирует данное культурное правило следующим образом:

[люди думают так:]

никто не может сказать другому человеку:

«я хочу, чтобы ты сделал это

ты должен сделать это из-за этого»

[люди думают так:]

никто не может сказать другому человеку:

«я не хочу, чтобы ты это делал

ты не можешь этого сделать из-за этого»

(Wierzbicka 2006a: 52)

Объясняя данные культурные сценарии, А. Вежбицкая отмечает, что в них «не говорится, что люди могут делать все, что хотят, или что не существует никаких установленных правил, которые запрещают людям делать то, что они хотят делать, скорее, они говорят о том, что желание другого человека не может помешать мне сделать то, что я хочу сделать, или заставить меня делать то, чего я делать не хочу» (Wierzbicka 2006a: 52).

6 Wh-импертив - это команда, просьба или иное побуждение, которое выражено в форме вопроса (например, Would you mind washing it out?, Could you just turn it down a bit?). Данный термин состоит из начальных букв английских вопросительных слов (wh) и слова императив. 
К. Годдард и А. Вежбицкая (2004: 156) формулируют еще одно похожее культурное правило англо-саксонской культуры, оберегающее ценность личной автономии:

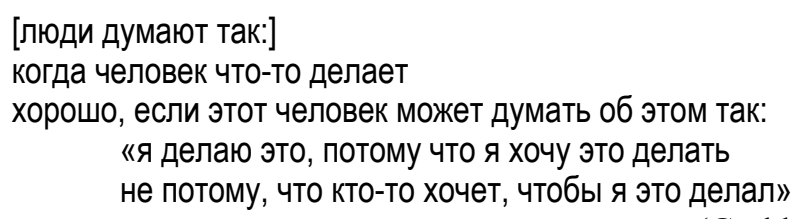

(Goddard, Wierzbicka 2004: 156)

Этот сценарий, формулирующий англосаксонскую культурную норму, тесно связан с английскими культурными ключевыми словами freedom 'свобода' и free 'свободный' (см. также [Ларина, Озюменко 2017]).

А. Вежбицкая далее показывает, что ценность личной автономии в английской культуре проявляется в недопустимости оказывать чрезмерное давление на других людей, что ярко отражено в английском языке (Wierzbicka 2006a, b). Среди многочисленных языковых фактов она называет выражения to put pressure 'оказывать давление' и to act under pressure 'действовать под давлением', которые не встречались в языке Шекспира, что, по мнению А. Вежбицкой, свидетельствует о том, как важно не оказывать давления на другого в современной английской культуре. Выражение to put pressure 'оказывать давление' и его негативная культурная коннотация подчеркивают мысль о том, что существует культурный запрет на навязывание своей воли другим людям и невозможность того, что человек будет совершать действие согласно воле других людей. Соответствующий культурный скрипт формулируется А. Вежбицкой следующим образом:

[люди думают так:]

когда я что-то делаю, хорошо, если я это делаю, потому что я хочу это делать, не потому, что кто-то хочет, чтобы я это делал

(Wierzbicka 2006a: 52)

Важно отметить, что скрипты, предложенные А. Вежбицкой, могут применяться не во всех вариантах английского языка. Из-за различных культурных норм такие культурные сценарии могут быть разными. В этой связи Дж. Вонг (Wong 2004) утверждает, что, хотя английский язык широко распространен в Сингапуре, коммуникативные стратегии сингапурского английского не полностью совпадают с англосаксонским английским (Anglo English), куда входят основные варианты английского языка. В частности, Дж. Вонг показывает, что сингапурский английский не имеет культурных сценариев личной автономии в виде приведенных выше скриптов. Он формулирует соответствующий культурный скрипт для сингапурского варианта английского языка следующим образом:

[люди думают так:]

когда я говорю кому-то о чем-то «я хочу, чтобы ты это сделал»,

я могу думать об этом так:

если этот человек может это сделать, этот человек сделает это

[люди думают так:]

когда кто-то говорит мне о чем-то «я хочу, чтобы ты это сделал», если я могу это сделать, это хорошо, если я это сделаю

(Wong 2004: 239) 
Культурные скрипты, сформулированные А. Вежбицкой (Wierzbicka 2006a) и Дж. Вонгом (Wong 2004), относятся к культурным правилам выражения просьбы и шире - побуждения в двух разных культурах. Использование одного и того же набора простых и универсальных слов делает культурные различия между этими правилами прозрачными и наглядными.

Через культурные скрипты А. Вежбицкая описала многие речевые акты, речевые жанры и коммуникативные практики в разных языках и культурах (см. Wierzbicka 2003/1991, 2002a, Вежбицкая 1996, 1999b, 2011 и др.). Она также продемонстрировала, что культурные скрипты могут применяться и для описания эмоций, их функций в коммуникации и их культурной специфики (см. [Альба-Хуэс, Ларина 2018, Ионова, Шаховский (этот выпуск), Вежбицкая 1999b, 2001c, Wierzbicka 1999a, 2018d] и др.).

Идея культурных скриптов А. Вежбицкой стала частью важного раздела прагматики - этнопрагматики. Ее простые формулировки того, что оценивается хорошо, а что плохо в той или иной культуре, имеют большой объяснительный потенциал и предотвращают негативные суждения и стереотипы. Например, ее идеи, касающиеся русского языка и культуры (Wierzbicka 2002a), где

хорошо, если человек хочет сказать другим людям, что этот человек думает (чувствует) плохо, если человек говорит другим людям, что этот человек думает (чувствует) что-то, если это не так

хорошо, если человек хочет, чтобы другие люди знали, что этот человек думает (чувствует)

помогают понять семантику русского слова искренность, которая значительно отличается от английского переводного эквивалента sincerity (см. [Gladkova 2017]), и объясняют многие особенности русского стиля коммуникации (чрезмерная, с точки зрения представителей многих западных культур открытость и недостаточная тактичность, прямолинейность и нелюбовь к формальному общению, часто свободное и неконтролируемое проявление эмоций и т.д.) (подробно см. [Ларина 2009, 2013]).

Теория культурных скриптов была успешно применена коллегами А. Вежбицкой к различным языкам, среди которых австралийский английский и другие варианты английского языка (Goddard 2012, 2015, 2016), сингапурский английский (Wong, 2004, 2014), африканские языки (Ameka 2006), китайский язык (Ye 2004), корейский (Yoon 2004), русский (Гладкова 2010b, Gladkova 2010c, 2013a, b, 2017), японский (Asano-Cavanagh 2016, Hasada 2006), датский (Levisen 2012, 2013), французский (Peeters 2013, 2014), итальянский (Farese 2018) и др.

Подход А. Вежбицкой к рассмотрению языка через призму культуры получил отклик в исследованиях многих российских ученых. Прежде всего это возглавляемая Ю.Д. Апресяном Московская семантическая школа, с которой А. Вежбицкую связывает долгое и плодотворное сотрудничество (например, [Апресян 1995, 2006, 2014; V. Apresjan 2018]). Многочисленные исследования московской группы культурной семантики, нацеленные на реконструкцию концептуализации мира в русской лингвокультуре, на выявление культурной семантики языковых единиц и экспликацию культурных кодов, проводились параллельно с исследованиями 
А. Вежбицкой и продемонстрировали много общего во взглядах на язык, культуру и их взаимодействие (Зализняк 2013, Зализняк, Левонтина, Шмелев 2005, 2012, Зализняк, Падучева 2018, Шмелев 2002, 2018 и др.). Работы А. Вежбицкой дали мощный импульс исследованиям многих российских ученых в области лингвокультурологии (Богданова 2015, 2017; Добричев, Козлова, Пшенкина 2013; Зыкова 2017, Иванова 2003, 2004, 2016, Иванова, Чанышева 2010; Карасик 2002, 2009, 2015, 2016; Ковшова 2013, Красных 2002, Ларина, Озюменко 2016, Larina et al. 2017 a,b, и др.), антропологической лингвистики (Карасик 2010), эмотиологии (Шаховский 2008, 2010, 2015, 2018; Волкова, Панченко 2018), коммуникативной этностилистики (Ларина 2007, 2009, Larina 2015), этнограмматики (Козлова 2009), межкультурной коммуникации (Ларина 2013, 2017; Леонтович 2005, 2007; Привалова 2005, Тер-Минасова 2000, Klyukanov, Leontovich 2017) и других исследовательских направлений, изучающих человека как представителя определенной лингвокультуры в его речевой деятельности.

Теория ключевых слов языка и культуры и культурных скриптов А. Вежбицкой обладает также огромным потенциалом использования в преподавании и изучении иностранных языков. Предложенные подходы к изучению языка через призму культуры дают возможность найти ответ, почему в разных культурах люди говорят по-разному. Они помогают просто и ясно объяснить прагматические правила использования языка в той или иной культуре и приспособиться к другому стилю общения. Теория А. Вежбицкой позволяет увидеть, что язык - это неотъемлемая часть культуры, которая глубоко укоренена в его структуре и формирует коммуникативные этностили, отражающие мировоззрение, ценности, отношения и идентичность говорящих на этом языке людей. Внедрение методологии А. Вежбицкой в преподавание языка способствует развитию межкультурной коммуникативной компетенции учащихся. Посредством ключевых слов и культурных скриптов они учатся понимать многие особенности изучаемого языка и культуры, видеть их системную взаимосвязь и логику. В результате они приобретают культурную восприимчивость, способность к анализу и критическому мышлению, обеспечивающим эффективность и успешность межкультурного диалога (см., например, [Goddard 2010b, Goddard and Wierzbicka 2007, Kurteš et al. 2017, Ozyumenko, Larina 2018, Wong 2018]).

\section{3. ДАЛЬНЕЙШЕЕ РАЗВИТИЕ И ПРИМЕНЕНИЕ ЕСМ: МИНИМАЛЬНЫЙ ЯЗЫК}

В книге Imprisoned in English: The Hazards Of English As A Default Language (Wierzbicka 2014) А. Вежбицкая представила свою идею о минимальном английском (Minimal English), который, по ее мнению, может стать «общим вспомогательным языком-посредником для говорящих на разных языках», и затем она выдвинула идею о возможности описания любого языка в виде «минимального языка» (Wierzbicka 2018). Эта идея получила дальнейшее развитие в книге (Goddard, Wierzbicka 2018). Язык-посредник основан на результатах лингвистических исследований, которые были использованы в разработке ЕСМ. Однако универсальные понятия, применяемые в ЕСМ, используются в нем наряду с более сложным словарем. Выбор 
понятий не является случайным, он опирается на результаты лингвистических исследований и включает в себя так называемые семантические молекулы (Goddard 2016). Можно надеяться, что, как и в случае с ECM, версии этого метаязыка могут быть разработаны и для других языков (например, минимальный русский, минимальный испанский, минимальный французский и т. д.).

В книге под редакцией К. Годдарда, посвященной минимальному английскому (Goddard ed. 2018), содержатся примеры применения минимального английского в различных областях. А. Вежбицкая, являющаяся активным разработчиком идеи минимального английского, приводит в этой книге примеры его использования в преподавании естествознания детям, а также в формулировании принципов Устава глобальной этики (Wierzbicka 2018a, b).

А. Вежбицкая демонстрирует эффективность минимального языка и в своей новой книге $W$ co wierza chrześcijanie? Opowieści o Bogu i o ludziach (Bo что верят христиане: история Бога и людей), вышедшей на польском языке в 2017 г. в Кракове. Расширенная версия этой книги на английском языке What Christians Believe: The Story of God and People будет опубликована издательством Oxford University Press в 2019 году (Wiezbicka in press). Книга пересказывает и переосмысливает основы христианской веры в простых словах и предложениях, которые могут быть понятны каждому человеку и которые могут быть перекрестно переведены на любой язык. Книга представляет собой семантический и теологический эксперимент, и в то же время это эксперимент по межкультурной коммуникации на минимальном языке. Минимальный польский и минимальный английский в ней совпадают в каждом слове и в каждой фразе.

Минимальный английский набирает силу, и уже есть несколько исследований, проведенных коллегами А. Вежбицкой, которые свидетельствуют о его успешном использовании в таких областях, как нарративная медицина (Peeters, Marini 2018), проблемы недееспособности и психического здоровья (Jordan 2017), дипломатия (Maley 2018; Farrelly, Wesley 2018), правозащитный дискурс (Mooney 2018) и др.

\section{4. СТАТЬИ ЭТОГО ВЫПУСКА}

Открывает выпуск давний друг Анны Вежбицкой польский лингвист Ежи Бартминьский (Люблин, Польша), хорошо известный российскому читателю по книге «Языковой образ мира: очерки по этнолингвистике» (Бартминьский 2005). С представляемым им сообществом лингвистов, сосредоточенных вокруг публикуемого в Люблине журнала "Etnolingwistyka” (Этнолингвистика), и Университетом им. Марии Склодовской-Кюри Анну Вежбицкую связывают давнее сотрудничество и научные подходы. В своей статье Ежи Бартминьски показывает близость научных концепций Вежбицкой и люблинских этнолингвистов, их противостояние таксономическим подходам к изучению смысла и принятие принципа субъективной реконструкции, вытекающего из философии языка Вильгельма Гумбольдта. Обе научные школы исходят из того, что изучать смысл слов необходимо в контексте общественной жизни, истории и национальной культуры. В статье автор фокусирует свое внимание на концепции когнитивных дефиниций, рассматривает ее генезис, принципы построения и наиболее важные идеи. Хотя сама концепция 
была создана как продолжение исследований языка фольклора независимо от работ А. Вежбицкой и ее метода Естественного Семантического Метаязыка (ECM), автор прослеживает между ними четкие параллели, обращая также внимание на некоторые различия. На примере концепта HOME/HOUSE в статье рассматриваются новые перспективы применения когнитивных дефиниций в сопоставительных исследованиях.

Анна А. Зализняк (Москва, Россия) представляет в своей статье концепцию Каталог семантических переходов (КСП) и излагает ее актуальное состояние. Основными категориями данной концепции, как отмечает автор, являются семантический переход, понимаемый как отношение когнитивной смежности между двумя языковыми значениями, и понятие реализации семантического перехода. Автор подчеркивает, что область типологии семантических переходов находится на пересечении областей семантической, лексической и грамматической типологий, но ни с одной из них не совпадает и убедительно доказывает, что данная концепция является инструментом выявления и описания в формате базы данных семантических переходов, воспроизводимых в языках мира в форме синхронной полисемии и/или диахронической семантической эволюции. В статье намечаются перспективы исследования и сферы применения его результатов. Отмечается, в частности, что языковой материал, содержащийся в Базе данных семантических переходов, может быть использован для формирования семантического критерия реконструкции, для выявления когнитивных механизмов языковой концептуализации, для описания типологических и ареальных особенностей семантической системы одного языка или группы языков.

В центре внимания статьи французского исследователя Алена Польгера (Нанси, Франция) находится понятие кополисемии, которое тесно связано с регулярной полисемией. Отмечая, что в разных научных контекстах полисемия определяется по-разному, автор рассматривает полисемию как свойство вокабулы (заглавного слова словарной статьи) объединять несколько значений слова, в то время как моносемия рассматривается как противоположное этому свойство. В статье обоснована необходимость изучения данного явления и представлены последние результаты исследования кополисемии во французском языке, позволившего системно выявить модели кополисемии, на которых, по мнению автора, основана регулярная полисемия, и формально описать полисемические структуры нескольких тысяч французских вокабул. Эта работа является частью широкомасштабного лексикографического проекта по созданию Французской Лексической Сети (fr-LN). В статье подчеркивается, что, хотя данное исследование проводится на материале французской лексики, предложенный подход моделирования полисемии может быть применен и к другим естественным языкам.

С.В. Иванова (Санкт-Петербург, Россия) и 3.3. Чанышева (Уфа, Россия) рассматривают сквозь призму научных взглядов А. Вежбицкой особенности проявления культурной семантики лексических единиц в политическом дискурсе. На примере лексических единиц английского языка whistleblower, kangaroo ticket, log cabin president, Camelot presidency, redneck и др. авторы показывают, как, наряду с лексическим значением, зафиксированным в словаре, лексемы способны 
порождать различные культурные смыслы, манифестация которых наблюдается в дискурсе. Исходным положением, определяющим подход к анализу лексических единиц, является понимание лексической единицы как знака культуры. Смысловой анализ производится с опорой на разные уровни организации культуры как единого целого с учетом динамики культурного универсума (Иванова 2016). Такой подход дает возможность выявить те смысловые наслоения в содержании рассматриваемых лексических единиц, которые отражают закрепление новых ценностей в обществе. Данная процедура интерпретации смыслов позволяет выйти на основополагающие культурные практики, которые характеризуют лингвокультурное сообщество, и на ядро культуры, с одной стороны, а с другой - вскрыть ту динамику, которой оно подвержено, что представляет несомненный интерес для лингвистов, работающих в области культурной и интерпретативной семантики, лингвокультурологии и дискурс-анализа.

Л.И. Богданова (Москва, Россия) продолжает развивать тему выявления оценочных смыслов (см. [Богданова 2017]), но в этот раз на материале грамматики. В ее статье этого выпуска показано, как идея семантической основы грамматики, выдвинутая и разработанная А. Вежбицкой, находит продолжение, связанное с изучением роли и места оценочных смыслов в продуктивной грамматике русского языка. Автор ставит перед собой цель выявить оценочные смыслы, важные для грамматики, и показать, каким образом субъективный компонент значения глагола влияет на способ выражения его актантных позиций. В статье показана установленная в ходе исследования взаимосвязь интеллектуальных и эмоциональных оценочных характеристик глагола, которые имеют выход в грамматику. Отмечается, что оценка (как положительная, так и отрицательная), содержащаяся в глагольной семантике, влияет на синтагматическое поведение глагола избирательно, что требует дополнительных усилий в установлении тех семантических зон, где роль оценочного компонента в грамматическом оформлении актантных позиций оказывается наиболее значимой. Автор ставит вопрос о возможности выявления вектора оценочной ориентации в русской грамматике и намечает дальнейшие перспективы изучения глагольной семантики, позволяющие определить новый ракурс для раскрытия национально-специфического мировидения, что могло бы способствовать развитию сравнительной аксиологии.

Тема этнокультурного потенциала грамматики развивается и в статье Л.А. Козловой (Барнаул, Россия), автора уникальной монографии «Этнокультурный потенциал грамматического строя языка и его реализация в грамматике говорящего» (Козлова 2009). Ее статья относится к области этнограмматики, занимающейся реконструкцией специфики культуры на основе анализа грамматических явлений и выявлением способов кодирования культурно-специфического семантического содержания в грамматике языка. Как справедливо отмечает автор, основателем данного направления по праву является А. Вежбицкая, которая впервые высказала мысль о том, что не только лексикон, но и грамматика языка принимает активное участие в репрезентации концептов, имеющих особую значимость для определенного лингвокультурного сообщества. В данной статье на материале английского языка в этнокультурном ракурсе проанализированы 
средства выражения залоговых значений с целью выявление факторов этнокультурного характера, которые влияют на их выбор в различных видах дискурса. В статье показана эволюция взглядов на категорию залога в контексте меняющихся парадигм научного знания, изложена сущность залоговых отношений с позиции функционального и когнитивного-дискурсивного подходов и сделана попытка выявить факторы этнокультурного характера, которые влияют на выбор категориальных и некатегориальных залоговых форм в разных видах дискурса.

В.И. Карасик (Москва, Россия), хорошо известный российскому лингвистическому сообществу своими интереснейшими исследованиями в области взаимодействия языка и культуры (Карасик 2002, 2009, 2010, 2016 и др.), посвятил свою статью алгоритмам построения комических текстов. Как справедливо отмечает автор, поскольку желание пошутить универсально, юмористическая интенция в меньшей мере характеризуется лингвокультурной спецификой и зависит от индивидуальных особенностей личности, в то время как понимание шутки вплетено в общий контекст культуры. Цель данной статьи - рассмотреть семиотические характеристики интерпретации комических текстов и обсудить семантические, прагматические и синтактические признаки таких вербальных образований. На материале русского языка (анекдотов, шутливых афоризмов, демотиваторов) в статье рассматриваются модели смехового поведения, описываются семантические и прагматические механизмы образования комического текста, выделяются две модели алгоритмов создания и понимания комических текстов: совмещение линий реальности и совмещение линий сообщения о реальности, которые представляют собой диктальное и модусное осмысление факта. Все теоретические положения сопровождаются богатым иллюстративным материалом, который непременно вызовет улыбку читателя.

B.В. Дементьев (Саратов, Россия), активно развивающий в своих трудах теорию непрямой коммуникации (Дементьев 2006), посвятил свою статью национальному своеобразию русской непрямой коммуникации, которое он описывает, применяя модель А. Вежбицкой, видоизмененную для целей его исследования. Автор основывает свое исследование на оппозиции персональности имперсональности, которая, по его мнению, представляет собой языковую и речевую категорию, охватывающую большинство уровней и сфер русского языка и речи. В статье обсуждается ряд актуальных процессов современной русской речи, обусловливающих обращение к планируемой непрямой коммуникации и изменения в способах такого обращения.

В рубрике «Научные доклады», которую мы открываем в данном выпуске, представлен доклад профессора А. Жолковского (Лос-Анджелес, США) «Спискомания, или Каталоги как прием (с примерами из поэзии и прозы, классической и современной, западной и русской)», прочитанный им в Калифорнийском университете в Беркли 31 марта 2014.

Завершают выпуск две обзорные статьи, посвященные темам, находящимся в центре внимания А. Вежбицкой. Статья С.В. Ионовой (Москва, Россия) и В.И. Шаховского (Волгоград, Россия) представляет обзор актуальных аспектов 
лингвокультурологической теории эмоций А. Вежбицкой, составляющей важнейшую часть ее научных воззрений. В статье Н.Ю. Найденовой (Москва, Россия) дается анализ исследований взаимодействия языка и религии в современной, главным образом, российской лингвистической науке.

\section{5. ЗАКЛЮЧЕНИЕ}

В данной статье была предпринята попытка обобщить вклад А. Вежбицкой в исследования взаимодействия языка и культуры. Основное внимание было уделено концепции ключевых слов языка и культуры и теории культурных скриптов, которые имеют широкое теоретическое и практическое применение в этнопрагматике, анализе текста и дискурса, межкультурной коммуникации, преподавании иностранных языков и т.д. В ней также были рассмотрены последние разработки А. Вежбицкой, в частности, минимальный английский.

Мы признаем, что это очень краткий обзор научных интересов и основных исследовательских направлений А. Вежбицкой, который не дает полного представления о ее работах. Мы ограничились целью познакомить российских и зарубежных читателей нашего журнала лишь с ее основными идеями и понятиями. Исследовательская парадигма А. Вежбицкой обширна, и она не может быть рассмотрена и полностью представлена в рамках одной статьи. Разнообразие и многогранность ее подхода к анализу языка и культуры допускает множество способов его интерпретации, свидетельством чему являются статьи этого выпуска, и поэтому каждый читатель сможет увидеть в них для себя что-то интересное, что подтолкнет его к новым идеям и исследованиям.

От имени редколлегии журнала, всех наших авторов и читателей мы еще раз от всей души поздравляем дорогую Анну с юбилеем и желаем много лет радости, счастья и творчества!

\section{БЛАГОДАРНОСТИ}

Мы благодарим авторов этого номера за их статьи и участие в процессе рецензирования, а также рецензентов за их ценные комментарии и активное участие в подготовке номера. Мы также благодарим всех читателей, которые проявили большой интерес к первому тому нашего специального выпуска, и надеемся, что это его продолжение найдет не меньший отклик.

(C) Anna Gladkova, Tatiana Larina, 2018 А.Н. Гладкова, Т.В. Ларина, 2018

\section{REFERENCES / СПИСОК ЛИТЕРАТУРЫ}

Alba-Juez, Laura and Larina, Tatiana (2018). Language and Emotion: Discourse-Pragmatic Perspectives. Russian Journal of Linguistics, 22 (1), 9-37. doi 10.22363/2312-9182-2018-22-1-9-37.

Ameka, Felix (2006). "When I die, don't cry": the ethnopragmatics of "gratitude" in West African languages. In Goddard, Cliff (ed.) Ethnopragmatics: Understanding discourse in cultural context. Berlin: Mouton de Gruyter, 231-266.

Asano-Cavanagh, Yuko (2016). Being 'indecisive' in Japanese: Analysis of kana, darou ka and (n) janai ka. Studies in Language, 40(1), 63-92. 
Apresjan, Valentina (2018). Russian Constructions with Syntactic Reduplication of Colour Terms: A Corpus Study. Russian Journal of Linguistics, 22 (3), 653 - 674. doi: 10.22363/2312-91822018-22-3-653-674.

Besemeres, Mary and Anna Wierzbicka (eds.) (2007). Translating lives: Living with two languages and cultures. St. Lucia: University of Queensland Press.

Bromhead, Helen (2009). The Reign of Truth and Faith: Epistemic Expressions in 16th and 17th Century English. Berlin/New York: Mouton de Gruyter.

Farese, Gian Marco (2018). The Cultural Semantics of Address Practices: A contrastive study between English and Italian. Lanham: Lexington Books.

Farrelly, Nicholas and Michael Wesley (2018). Internationalizing Minimal English: Perils and Parallels. In Cliff Goddard (ed.) Minimal English for a global world: Improved communication using fewer words, 95-112.

Gladkova, Anna (2010a). 'Sympathy', 'compassion', and 'empathy' in English and Russian: A linguistic and cultural analysis. Culture \& Psychology, 16 (2), 267-285.

Gladkova, Anna. (2013a). "Is he one of ours?" The cultural semantics and ethnopragmatics of social categories in Russian. Journal of Pragmatics, 55, 180-194. http://dx.doi.org/10.1016/ j.pragma.2013.06.010.

Gladkova, Anna (2013b). 'Intimate' talk in Russian: human relationships and folk psychotherapy. Australian Journal of Linguistics, 33, 322-343.

Gladkova, Anna (2017). Communication Modes, Russian. In Kim, Young Yun (ed.) The International Encyclopedia of Intercultural Communication. Hoboken, NJ: Wiley. doi: 10.1002/9781118783665.ieicc0147.

Gladkova, Anna and Larina, Tatiana (2018). Anna Wierzbicka, Words and the World. Russian Journal of Linguistics, 22 (3), 499-520. doi: 10.22363/2312-9182-2018-22-3-499-520.

Goddard, Cliff (2006). Ethnopragmatics. A new paradigm. In Goddard, Cliff (ed.) Ethnopragmatics: Understanding discourse in cultural context. Berlin: Mouton de Gruyter, 1-30.

Goddard, Cliff (2010a). The Natural Semantic Metalanguage approach. In Bernd Haine and Heiko Narrog (eds.) The Oxford Handbook of Linguistic Analysis. United Kingdom: Oxford University Press, $459-484$.

Goddard, Cliff (2010b). Cultural scripts: applications to language teaching and intercultural communication. In C. Goddard (ed.) Studies in Pragmatics 3. China: China-Pub.com, 105-119.

Goddard, Cliff (2012). "Early interactions" in Australian English, American English, and English English: Cultural differences and cultural scripts. Journal of Pragmatics, 44 (9), 1038-1050.

Goddard, Cliff (2015). Swear words and curse words in Australian (and American) English. At the crossroads of pragmatics, semantics and sociolinguistics. Intercultural Pragmatics, 12 (2), $189-218$.

Goddard, Cliff (2016). Ethnopragmatic perspectives on conversational humour, with special reference to Australian English. Language \& Communication, 1-14.

Goddard, Cliff (2018). Minimal English: The Science Behind It. In Minimal English for a Global World: Improved Communication Using Fewer Words, 29-70.

Goddard, Cliff and Cramer, Rahel (2017). Laid back and irreverent: An ethnopragmatic analysis of two cultural themes in Australian English communication. In C. Donal (ed.) Handbook of Communication in Cross-Cultural Perspective, 89-103.

Goddard, Cliff and Anna Wierzbicka (2004). Cultural scripts: What are they and what are they good for? Intercultural Pragmatics 1-2: 153-166. 
Goddard, Cliff and Anna Wierzbicka (2007). Semantic primes and cultural scripts in language learning and intercultural communication. In Sharifian, Farzad and Gary Palmer (eds.) Applied Cultural Linguistics: Implications for second language learning and intercultural communication. Amsterdam: John Benjamins, 105-124.

Goddard, Cliff and Wierzbicka, Anna (2018). Minimal English and How It Can Add to Global English. In Cliff Goddard (ed.) Minimal English for a Global World: Improved Communication Using Fewer Words, 5-27.

Goddard, Cliff (ed.) (2018). Minimal English for a Global World: Improved Communication Using Fewer Words. London: Palgrave Macmillan.

Goddard, Cliff and Anna Wierzbicka (eds.) (1994). Semantic and lexical universals: Theory and empirical findings. Amsterdam: John Benjamins.

Goddard, Cliff and Anna Wierzbicka (eds.) (2002). Meaning and Universal Grammar: Theory and empirical findings. Vols. I, II. Amsterdam: John Benjamins.

Goddard, Cliff and Anna Wierzbicka (eds.) (2004). Intercultural Pragmatics, 1-2.

Hasada, Rie (2006). Cultural scripts: Glimpses into the Japanese emotion world. In Cliff Goddard (ed.) Ethnopragmatics: Understanding Discourse in Cultural Context. Berlin: Mouton de Gruyter, $171-198$.

Jordan, Paul (2017). How to start, carry on and end conversations: Scripts for social situations for people on the autism spectrum. London: Jessika Kingsley Publishers.

Klyukanov, Igor and Leontovich, Olga. (2017). Russian Perspectives on Communication. In Donal Carbaugh (ed.). The Handbook of Communication in Cross-Cultural Perspective. NY: Routledge, $29-41$.

Kurteš, Svetlana, Tatiana Larina, and Vladimir Ozyumenko (2017). Constructivist approach to intercultural communication teaching and learning. EDULEARN17 Proceedings. 9th International Conference on Education and New Learning Technologies. Barcelona, Spain. 3-5 July, 2017, 591—59. doi: 10.21125/edulearn.2017.1127.

Larina, Tatiana (2015). Culture-Specific Communicative Styles as a Framework for Interpreting Linguistic and Cultural Idiosyncrasies. International Review of Pragmatics, 7 (5). Special Issue: Communicative Styles and Genres, 195-215.

Larina, Tatiana, Vladimir Ozyumenko, and Svetlana Kurteš (2017). I-identity vs we-identity in language and discourse: Anglo-Slavonic perspectives. Lodz Papers in Pragmatics, 13 (1), 2017, 109-128.

Larina, Tatiana, Arto, Mustajoki, and Ekaterina Protassova (2017). Dimensions of Russian culture and mind. In Katja Lehtisaari and Arto Mustajoki (eds.) Philosophical and cultural interpretations of Russian modernisation. Series: Studies in Contemporary Russia. London/New York: Routledge, 7-19.

Levisen, Carsten (2012). Cultural Semantics and Social Cognition. A case study of the Danish universe of meaning. Berlin: Mouton de Gruyter.

Levisen, Carsten (2013). On pigs and people: the porcine semantics of Danish interaction and cognition. Australian Journal of Linguistics, 33, 344-364.

Levisen, Carsten and Sophia Waters (eds.) (2018). Cultural Keywords in Discourse. Amsterdam: John Benjamins.

Maley, William (2018). Minimal English and Diplomacy. In Cliff Goddard (ed.) Minimal English for a global world: Improved communication using fewer words, 71-93.

Mooney, Annabelle (2018). Torture Laid Bare: Global English and Human Rights. In Cliff Goddard (ed.) Minimal English for a global world: Improved communication using fewer words, $143-167$. 
Ozyumenko, Vladimir and Tatiana Larina (2018). Cultural Semantics in Second Language Teaching: A case study of Russian drug and English friend. INTED2018 Proceedings, 12th International Technology, Education and Development Conference, Valencia, Spain, 5-7 March, 2018, 9149-9158. doi: 10.21125/inted.2018.2235.

Peeters, Bert (2013). Râler, râleur, râlite: discours, langue et valeurs culturelles [Râler, râleur, râlite: Discourse, language and cultural values]. In C. Claudel, P. von Münchow, M. Pordeus, F. PugnièreSaavedra \& G. Tréguer-Felten (eds.) Cultures, discours, langues: nouveaux abordages. Limoges: Lambert-Lucas, 117-141.

Peeters, Bert (2014). On va s'arranger/On s'arrangera: étude ethnophraséologique de deux actes (généralement) rassurants [On va s'arranger/On s'arrangera: An ethnophraseological study of two (generally) reassuring speech acts]. Scolia, 28, 129-149.

Peeters, Bert and Marini, Maria Giulia (2018). Narrative Medicine across languages and cultures: Using Minimal English for increased comparability of patients' narratives. In Cliff Goddard (ed.) Minimal English for a global world: Improved communication using fewer words. London: Palgrave Macmillan, 259-286.

Travis, Catherine (2006). The communicative realization of confianza and calor humano in Colombian Spanish. In Goddard, Cliff. (ed.) Ethnopragmatics: Understanding discourse in cultural context. Berlin: Mouton de Gruyter, 199-230.

Wierzbicka, Anna (1990). Duša ('soul'), toska ('yearning'), sud'ba ('fate'): three key concepts in Russian language and Russian culture. In Saloni, Zygmunt (ed.) Metody formalne w opisie języków stowiańskich. Bialystok University Press, 13-36.

Wierzbicka, Anna (1997a). Understanding cultures through their key words: English, Russian, Polish, German, and Japanese. Oxford: Oxford University Press.

Wierzbicka, Anna (1997b). The double life of a bilingual: A cross-cultural perspective. Anna Wierzbicka. 1997. In Michael Bond (ed.), Working at the Interface of Culture: Eighteen lives in social science. London: Routledge, 113-125.

Wierzbicka, Anna (1999a). Emotions across Languages and Cultures: Diversity Universals. Cambridge: Cambridge University Press.

Wierzbicka, Anna (2001a). What did Jesus mean? Oxford: Oxford University Press.

Wierzbicka, Anna (2001b). Culturally salient Polish emotion: Przykro [pshickro]. The International Journal of Group Tensions 30(1), 3-27. (Special Issue on "Emotions in Cultural Contexts in Space and Time" edited by W. Gerrod Parrott and Rom Harré.)

Wierzbicka, Anna. (2002a). Russian cultural scripts: The theory of cultural scripts and its applications. Ethos 30 (4), 401-432.

Wierzbicka, Anna (2002b). Australian cultural scripts — bloody revisited. Journal of Pragmatics, 34 (9), 1167-1209.

Wierzbicka, Anna (2003/1991). Cross-Cultural Pragmatics. $2^{\text {nd }}$ ed. Berlin: Mouton de Gruyter.

Wirzbicka, Anna. (2006a) English: Meaning and Culture. Oxford: Oxford University Press.

Wierzbicka, Anna (2006b). Anglo scripts against "putting pressure" on other people and their linguistic manifestations. In Goddard, Cliff (ed.) Ethnopragmatics: Understanding discourse in cultural context. Berlin: Mouton de Gruyter, 31-63.

Wierzbicka, Anna (2007). Two languages, two cultures, one (?) self: Between Polish and English. In Besemeres, Mary and Anna Wierzbicka (ed.). Translating Lives: Living with Two Languages and Cultures. St Lucia, Australia: University of Queensland Press, 96-113.

Wierzbicka, Anna (2010a). Experience, Evidence, and Sense: The hidden cultural legacy of English. New York: Oxford University Press.

Wierzbicka, Anna (2010b). Cross-cultural communication and miscommunication: the role of cultural keywords. Intercultural Pragmatics, 7 (1), 1-23. 
Wierzbicka, Anna (2011a). Common language of all people: the innate language of thought. Problems of information transmission, 47, 378-397. English translation of a Russian text (2011) published in Problemy Peredachi Informatsii, 47(4), 84-103.

Wierzbicka, Anna (2014). Imprisoned in English: The Hazards of English as a Default Language. Oxford: Oxford University Press.

Wierzbicka, Anna (2017). W co wierza chrześcijanie? Opowieść o Bogu i o ludziach (What Christians Believe: The Story of God and People). Cracow: Znak.

Wierzbicka, Anna (2018a). Charter of Global Ethic in Minimal English. In Cliff Goddard (ed.) Minimal English for a global world: Improved communication using fewer words, 113-141.

Wierzbicka, Anna (2018b). Talking About the Universe in Minimal English: Teaching Science Through Words That Children Can Understand. In Cliff Goddard (ed.) Minimal English for a global world: Improved communication using fewer words, 169-200.

Wierzbicka, Anna (2018c). Emotions of Jesus. Russian Journal of Linguistics, 22 (1), 38-53. doi: 10.22363/2312-9182-2018-22-1-38-53.

Wierzbicka, Anna (In press). What Christians Believe: The Story of God and People in Minimal English. Oxford: Oxford University Press.

Wong, Jock (2004). Cultural scripts, ways of speaking and perceptions of personal autonomy: Anglo English vs. Singapore English. Intercultural Pragmatics, 1 (2), 231-248.

Wong, Jock (2014). The Culture of Singapore English. Cambridge University Press.

Wong, Jock Onn (2018). The Semantics of Logical Connectors: therefore, moreover and in fact. Russian Journal of Linguistics, 22 (3), 581 - 604. doi: 10.22363/2312-9182-2018-22-3-581-604.

Ye, Zhengdao (2004). Chinese categorization of interpersonal relationship and the cultural logic of Chinese social interaction: An indigenous perspective. Intercultural Pragmatics, 1 (2), 211-230.

Ye, Zhengdao (2013). Understanding the conceptual basis of the 'old friend' formula in Chinese social interaction and foreign diplomacy: A cultural script approach. Australian Journal of Linguistics, 33 (3), 365-385.

Yoon, Kyung-Joo (2004). Not just words: Korean social models and the use of honorifics. Intercultural Pragmatics, 1 (2), 189-210.

Апресян Ю.Д. Избранные труды. Т. 1-2. М.: Языки русской культуры, 1995. [Apresjan Yu.D. (1995). Izbrannye Trudy (Selected papers). Vol. 1-2. Moscow: Yazyki russkoi kul'tury Publ. (In Russ.)]

Апресян Ю.Д. (ред.). Языковая картина мира и системная лексикография. М.: Языки славянских культур, 2006 [Apresjan Yu.D. (ed.) (2006). Yazykovaya kartina mira i sistemnaya leksikografiya. Moscow: Yazyki slavyanskikh kul'tur Publ. (In Russ.)]

Апресян Ю.Д. (ред.). Активный словарь русского языка. Т. 1-2. М.: Языки славянской культуры, 2014. [Apresjan Yu.D. (ed.) (2014). Aktivnyi slovar' russkogo yazyka. T. 1—2. М.: Yazyki slavyanskoi kul'tury (In Russ.)]

Богданова Л.И. Новые слова в аспекте взаимодействия языков и культур. Вестник Российского университета дружбы народов. Серия Лингвистика. 2015. № 2. С. 41-50. [Bogdanova, L. (2015). New Words in Interaction of Languages and Cultures. Russian Journal of Linguistics, 2, 41-50. (In Russ.)]

Богданова Л.И Оценки и ценности в зеркале словарей русского языка // Вестник Российского университета дружбы народов. Серия: Лингвистика. 2017. Т. 21. № 4. С. 729-748. [Bogdanova, L. (2017). The Reflection of Evaluation in Russian Language Dictionaries. Russian Journal of Linguistics, 21 (4), 729-748 (In Russ.)] doi 10.22363/2312-9182-2017-21-4729-748. 
Бартминьский Е. Языковой образ мира: очерки по этнолингвистике. М., 2005. [Bartmin'skii, Ezhi (2005). Yazykovoi obraz mira: ocherki po etnolingvistike (The Language Image of the World: Essays on Ethnolinguistics) Moscow (In Russ.)].

Вежбицкая А. Язылк. Культура. Познание. М., 1996. [Wierzbicka, Anna (1996b). Language. Culture. Cognition. Moscow. (In Russ.)]

Вежбицкая А. Семантические универсалии и описание языков / Пер. с англ. А.Д. Шмелева; под ред. Т.В. Булыгиной. М.: Языки русской культуры, 1999b. [Wierzbicka, Anna (1999b). Semantic universals and description of languages. Translated from English by A. Shmelev. Moscow, Yazyki russskoi kul'tury. (In Russ.)].

Вежбицкая А. Понимание культур через посредство ключевых слов / Пер. с англ. А.Д. Шмелева. М.: Языки славянской культуры, 2001c. [Wierzbicka, Anna (2001c). Understanding culture through keywords. Translated from English by A. Shmelev. Moscow: Yazyki slavyanskoi kul'tury. (In Russ.)]

Вежбицкая А. Сопоставление культур через посредство лексики и прагматики. М.: Языки славянской культуры, 2001d. [Wierzbicka, Anna (2001d). Comparison of cultures through vocabulary and pragmatics. Moscow: Yazyki slavyanskoi kul'tury. (In Russ.)]

Вежбицкая А. Семантические универсалии и базисные концепты. М.: Языки славянских культур, 2011. [Wierzbicka, Anna (2011). Semantic universals and basic concepts. Yazyki slavyanskikh kul'tur. (In Russ.)]

Волкова Я.А., Панченко Н.Н. Дискурсивная вариативность концептов деструктивных эмоций // Вестник Российского университета дружбы народов. Серия: Лингвистика. 2018. Т. 22. № 1. C. 175-194. [Volkova, Yana, Panchenko, Nadezhda (2018). Discourse Variation of the Concepts of Destructive Emotions. Russian Journal of Linguistics, 22 (1), 175-194. (In Russ.)] doi: 10.22363/2312-9182-2018-22-1-175-194.

Гладкова А.Н. Русская культурная семантика: Эмоции, иенности, жизненные установки. М.: Языки славянских культур. 2010b. [Gladkova, Anna (2010b). Russian cultural semantics: Emotions, values, attitudes. Moscow: Yazyki slavyanskoi kul'tury. (In Russ.)]

Добричев С.А., Козлова Л.А., Пшенкина Т.Г. Этнокульутрный потенцииал языковых единии различных уровне. Барнаул: АлтГПА, 2013. [Dobrichev S.A., Kozlova L.A., Pshenkina T.G. (2013). Etnokul'utrnyi potentsial yazykovykh edinits razlichnykh urovne. (Ethnocultural potential of language units at various levels). Barnaul: AltGPA Publ. (In Russ.)]

Дементьев В.В. Непрямая коммуникация. М.: Гнозис, 2006. [Dement'ev, Vadim. (2006). Nepryamaya kommunikatsiya (Indirect communication). Moscow: Gnozis Publ., 2006. (In Russ.)]

Зализняк Анна А. Русская семантика в типологической перспективе. М.: Языки славянской культуры, 2013. [Zalizniak, Anna (2013). Russkaya semantika v tipologicheskoi perspective (Russian semantics in a typological perspective). Moscow: Yazyki slavyanskoi kul'tury (In Russ.)]

Зализняк А.А., Левонтина И.Б., Шмелев А.Д. Ключевые идеи русской языковой картины мира. М.: Языки славянской культуры, 2005. [Zalizniak, Anna, Levontina, Irina, and Alexey Šmelev (2005). Ključevye idei russkoj jazykovoj kartiny mira (Key ideas of the Russian linguistic picture of the world). Moscow: Jazyki slavyanskoj kul'tury Publ. (In Russ.)]

Зализняк А.А., Левонтина И.Б., Шмелев А.Д. Константы и переменные русской языковой картины мира. М.: Языки славянской культуры, 2012. [Zalizniak, Anna, Levontina, Irina, and Alexey Šmelev (2012). Konstanty i peremennye russkoi yazykovoi kartiny mira. (Constants and variables of the Russian language picture of the world). Moscow: Jazyki slavyanskoj kul'tury Publ. (In Russ.)] 
Зализняк Анна А., Падучева Е.В. Опыт семантического анализа русских дискурсивных слов: пожалуй, никак, все-таки // Вестник Российского университета дружбы народов. Серия: Лингвистика. 2018. Т. 22. № 3. С. 628 - 652. [Zalizniak, Anna and Paducheva, Elena (2018). Towards a Semantic Analysis of Russian Discourse Markers: pozhaluj, nikak, vsjo-taki. Russian Journal of Linguistics, 22 (3), 628 - 652 (In Russ.)]. doi: 10.22363/2312-9182-201822-3-628-652.

Зыкова И.В. Метаязык лингвокультурологии: Константы и варианты. М.: Гнозис, 2017. [Zykova I.V. (2017). Meta-language of linguistic culturology: Constants and options. Moscow: Gnosis Publ., 2017 (In Russ.)]

Иванова С.В. Лингвокультурологический аспект исследования языковых единии. Уфа: Изд-во Баш. гос. ун-та, 2003. [Ivanova, S.V. (2003) Lingvokul'turologicheskiy aspekt issledovaniya yazykovykh yedinits (Linguocultural perspective of the study of language units). Ufa: Bashkir University Publ. (In Russ.)]

Иванова С.В. Лингвокультурология и лингвокогнитология: сопряжение парадигм. Уфа, 2004. [Ivanova, S.V. (2004). Lingvokul'turologiya i lingvokognitologiya: sopryazheniye paradigm (Linguistic culturology and linguistic cognitive science: conjugation of paradigms). Ufa (In Russ.)]

Иванова С.В. Лингвокультурология: изучая лингвокультурный универсум // Вестник РУДН. Серия: Лингвистика. 2016. Т. 20. № 2. C. 9-16. [Ivanova S.V. (2016). Cultural Linguistics: studying linguocultural universum. Russian Journal of Linguistics, 20 (2), 9-16. (In Russ.)]

Иванова С.В., Чанышева 3.З. Лингвокультурология: проблемы, поиски, решения. Уфа, 2010. [Ivanova S.V., Chanysheva Z.Z. Lingvokul'turologiya: problemy, poiski, resheniya (Linguoculturology: problems, searches, solutions). Ufa, 2010 (In Russ.)]

Карасик В.И. Языковой круг: личность, концепты, дискурс. Волгоград: Перемена, 2002.

[Karasik V.I. (2002) Yazykovoi krug: lichnost', kontsepty, diskurs (Language circle: Personality, concepts, discourse). Volgograd: Peremena Publ. (In Russ.)]

Карасик В.И. Языковые ключи. М.: Гнозис, 2009. [Karasik V.I. (2009). Yazykovye klyuchi (Language keys). Moscow: Gnozis Publ., 2009. (In Russ.)]

Карасик В.И. Языковая кристаллизачия смысла. Волгоград: Парадигма, 2010. [Karasik V.I. (2010). Yazykovaya kristallizatsiya smysla (Linguistic crystallization of meaning). Volgograd: Paradigma Publ., 2010. (In Russ.)]

Карасик В.И. Языковая спираль: иенности, знаки, мотивы. Волгоград: Парадигма, 2015. [Karasik V.I. (2015). Yazykovaya spiral': tsennosti, znaki, motivy ( Language Spiral: Values, Signs, Motives). Volgograd: Paradigma Publ. (In Russ.)]

Карасик В.И. Дискурсивное проявление личности // Вестник Российского университета дружбы народов. Серия: Лингвистика. 2016. Т. 20. o 4. C. 56-77. [Karasik, V.I. (2016). Discourse Manifestation of Personality. Russian Journal of Linguistics, 20 (4), 56-77] (In Russ.)] doi: 10.22363/231291822016204567.

Ковшова М.Л. Лингвокультурологический метод во фразеологии. Коды культуры. М.: УРСС, 2-е изд., 2013. [Kovshova M.L. (2013). Lingvokul'turologicheskii metod vo frazeologii. Kody kul'tury (Linguoculturological method in phraseology. Culture codes). Moscow: URSS Publ. (In Russ.)]

Козлова Л.А. Этнокультурный потенциал грамматического строя языка и его реализация в грамматике говорящего. Барнаул: АлтГПА, 2009. [Kozlova L. A. (2009). Etnokul'turnyi potentsial grammaticheskogo stroya yazyka i ego realizatsiya $v$ grammatike govoryashchego (Ethnocultural potential of the grammatical structure of the language and its implementation in the grammar of the speaker). Barnaul: AltGPA Publ. (In Russ.)] 
Красных В.В. Этнопсихолингвистика и лингвокультурология: Курс лекиий. М.: ИТДГК «Гнозис», 2002. [Krasnykh, V.V. (2002). Etnopsikholingvistika i lingvokul'turologiya (Ethnopsycholinguistics and linguistic cultural studies). Moscow: Gnozis Publ. (In Russ.)]

Ларина Т.В. Этностилистика в ее коммуникативном аспекте // Известия РАН. Серия литературы и языка, 2007. Том 66. № 3. С. 3-17. [Larina, Tatiana (2007). Etnostilistika $\mathrm{v}$ yeye kommunikativnom aspekte (Ethnostylistics in communicative perspective). Bulletin of the Russian Academy of Sciences. Literature and Language, 2007, 66 (3), 3-17. (In Russ.)]

Ларина Т.В. Категория вежливости и стиль коммуникации: Сопоставление английских и русских лингвокультурных традиций. М.: Языки славянских культур, 2009. [Larina, Tatiana (2009) Kategoriya vezhlivosti i stil' kommunikatsii: sopostavleniye angliiskikh $i$ russkikh lingvokul'turnykh traditsii (Politeness and communicative styles: Comparison of English and Russian language and culture traditions). Moscow: Jazyki Slavianskih Kul'tur Publ. (In Russ.)]

Ларина Т.В. Англичане и русские: Язык, культура, коммуникация. М.: Языки славянских культур, 2013 [Larina, Tatiana (2013) Anglichane i russkie: Yazyk, kul'tura, kommunikatsiya (The British and the Russians: Language, culture and communication). Moscow: Jazyki Slavianskih Kul'tur Publ. (In Russ.)]

Ларина Т.В. Основы межкультурной коммуникации: учебник для студ. учреждений высш. образования. М.: Издательский центр «Академия», 2017. [Larina, Tatiana (2017). Intercultural Communication. Moscow: Akademiya Publ. (In Russ.)]

Ларина Т.В., Озюменко, В.И. Этническая идентичность в языке и коммуникации [Larina, Tat'yana and Vladimir Ozyumenko (2016). Ethnic identity in language and communication. Cuadernos de Rusistica Espanola, 12, 57-68. (In Russ.)]

Ларина Т.В., Озюменко В.И. Свобода личности как конституирующий компонент английского дискурса. Известия Южного Федерального университета. Филологические науки. 2017. № 2. C. 160-172 [Larina, Tatiana, Vladimir Ozyumenko (2017). Personal freedom as a constitutive element of English discourse. Izvestiya Yuzhnogo Federal'nogo universiteta. Filologicheskie nauki, 2, 160 - 172 (In Russ.)]. doi: 10.23683/1995-0640-2017-2-160-172.

Леонтович О.А. Русские и американщы: парадоксы межкультурной коммуникации. М.: Гнозис, 2005. [Leontovich O.A. (2005). Russkie i amerikantsy: paradoksy mezhkul'turnoi kommunikatsii (The Russians and Americans: the paradoxes of intercultural communication). Moscow: Gnozis Publ. (In Russ.)]

Леонтович О.А. Введение в межкультурную коммуникачию. М.: Гнозис, 2007. [Leontovich О.А. (2007). Vvedenie v mezhkul'turnuyu kommunikatsiyu (Introduction to Intercultural Communication). Moscow: Gnozis Publ.(In Russ.)]

Привалова И.В. Интеркультура и вербальный знак (лингвокогнитивные основы межкультурной коммуникации). М.: Гнозис, 2005. [Privalova I.V. (2005). Interkul'tura i verbal'nyy znak (Lingvokognitivnyye osnovy mezhkul'turnoy kommunikatsii). (Interculture and a verbal sign (linguocognitive basis of intercultural communication). Moscow: Gnozis Publ. (In Russ.)]

Тер-Минасова С.Г. Язык и межкультурная коммуникация. М.: Слово, 2000. [Ter-Minasova, Svetlana (2000). Yazyk i mezhkul'turnaya kommunikatsiya (Language and intercultural communication). Moscow: Slovo Publ. (In Russ.)].

Шаховский В.И. Лингвистическая теория эмочий. М.: Гнозис, 2008. [Shahovsky, V.I. (2008). Lingvisticheskaya teoriya emotsii (Linguistic theory of emotions). Moscow: Gnozis Publ. (In Russ.)]

Шаховский В.И. Эмоции: Долингвистика, лингвистика, лингвокультурология. URSS Publ. 2010 [Shahovsky, V.I. (2010) Jemocii: Dolingvistika, lingvistika, lingvokul'turologiya [Emotions: Alinguistic, linguistics, cultural linguistics.]. Izd. stereotip. URSS Publ. (In Russ.)] 
Шаховский В.И. Голос эмоций в языковом круге homo sentiens. Изд. 3-е, стереотип. М.: Книжный дом «ЛИБРОКОМ», 2015. [Shahovsky, V.I. (2015). Voice of emotion in the linguistic circle of homo sentiens. 3-nd edition. Moscow: Knizhnyj dom «LIBROKOM» Publ. (In Russ.)]

Шаховский В.И. Когнитивная матрица эмоционально-коммуникативной личности // Вестник Российского университета дружбы народов. Серия: Лингвистика. 2018. Т. 22. № 1. C. 54-79. [Shakhovsky, Victor (2018) The Cognitive Matrix of Emotional-Communicative Personality. Russian Journal of Linguistics, 22 (1), 54 - 79 (In Russ.)] doi: 10.22363/2312-91822018-22-1-54-79.

Шмелев А.Д. Русская языковая модель мира: материалы к словарю. М.: Языки славянской культуры, 2002. [Šmelev, Alexey (2002). Russkaja jazykovaja model' mira: materialy $k$ slovarju (The Russian language model of the world: materials for a dictionary). Moscow: Jazyki slavjanskoj kul'tury. (In Russ.)]

Шмелев А.Д. Еще раз о русских словах свобода и воля // Вестник Российского университета дружбы народов. Серия: Лингвистика. 2018. Т. 22. № 3. С. 675-700. [Shmelev, Alexei (2018). Russian Words for 'Freedom' Revisited. Russian Journal of Linguistics, 22 (3), 675700. (In Russ.)] doi: 10.22363/2312-9182-2018-22-3-675-700.

\section{Electronic resources / Электронные ресурсы}

NSM-APPROACH.NET https://nsm-approach.net/

NSM Homepage https://intranet.secure.griffith.edu.au/schools-departments/natural-semanticmetalanguage

\section{For citation:}

Gladkova, Anna and Larina, Tatiana (2018). Anna Wierzbicka, Language, Culture and Communication. Russian Journal of Linguistics, 22 (4), 717-748. doi: 10.22363/2312-9182-2018-22-4-717-748.

\section{Для цитирования:}

Гладкова А.Н., Ларина Т.В. Анна Вежбицкая: язык, культура и коммуникация // Вестник Российского университета дружбы народов. Серия: Лингвистика = Russian Journal of Linguistics. 2018. T. 22. № 4. C. 717-748. doi: 10.22363/2312-9182-2018-22-4-717-748.

\section{Bionotes:}

ANNA GLADKOVA is a Lecturer in English as an International Language at Monash University and an Honorary Lecturer in Linguistics at the Australian National University. She received her PhD in Linguistics from the Australian National University. Her research interests include semantics, pragmatics, language and culture interface, cognitive linguistics and Natural Semantic Metalanguage. She has taught linguistics and applied linguistics at the Australian National University and University of New England (Australia) as well as University of Sussex and University of Brighton (United Kingdom). She is member of the Editorial Board of Corpus Pragmatics and Yearbook of Corpus Linguistics and Pragmatics (Springer).

Contact information: angladkova@gmail.com

TATIANA V. LARINA is Full Professor at RUDN University, and is the Editor-in-Chief of the Russian Journal of Linguistics. Her research interests embrace language, culture and communication; intercultural pragmatics, intercultural communication, communicative ethnostyles, and (im)politeness theory. Key publications: Kategoriya vezhlivosti i stil' kommunikatsii: sopostavlenie angliiskikh i russkikh lingvokul'turnykh traditsii [Politeness and Communicative Styles: comparative analyses of English and Russian communicative traditions], Moscow, 2009; Anglichane i russkie: Yazyk, kul'tura, kommunikatsiya [The English and the Russians: Language, Culture and Communication], 
Moscow, 2013; Osnovy mezhkul'turnoi kommunikatsii [Intercultural Communication], Moscow, 2017; Culture-Specific Communicative Styles as a Framework for Interpreting Linguistic and Cultural Idiosyncrasies. International Review of Pragmatics, 7 (3), 195-215, 2015.

Contact information: larina_tv@rudn.university

\section{Сведения об авторах:}

AHНА ГЛАДКОВА получила степень $\mathrm{PhD}$ по лингвистике в Австралийском национальном университете. Она преподает в Университете Монаш (Австралия), а также является почетным преподавателем лингвистики в Австралийском национальном университете. Ее научные интересы включают семантику, прагматику, взаимодействие языка и культуры, когнитивную лингвистику и Естественный Семантический Метаязык. Она преподавала лингвистику и прикладную лингвистику в Австралийском национальном университете и Университете Новой Англии (Австралия), а также в Университете Сассекса и Университете Брайтона (Великобритания). Она является членом редколлегии журнала Corpus Pragmatics и Yearbook of Corpus Linguistics and Pragmatics (издательство Springer).

Контактная информация: angladkova@gmail

ЛАРИНА ТАТЬЯНА ВИКТОРОВНА - докТор филологических наук, профессор кафедры иностранных языков филологического факультета Российского университета дружбы народов, главный редактор журнала Вестник Российского университета дружбы народов. Серия: Лингвистика / Russian Journal of Linguistics. Сфера научных интересов: язык, культура, коммуникация; межкультурная прагматика; межкультурная коммуникация; этнокультурные стили коммуникации; теория (не)вежливости. Основные публикации: Категория вежливости и стиль коммуникации: Сопоставление английских и русских лингвокультурных традиций. М.: Языки славянских культур, 2009; Англичане и русские: Язык, культура, коммуникация. М.: Языки славянских культур, 2013; Основы межкультурной коммуникаиии. М.: Академия, 2017; Culture-Specific Communicative Styles as a Framework for Interpreting Linguistic and Cultural Idiosyncrasies // International Review of Pragmatics, 7 (3), 195-215, 2015.

Контактная информация: larina_tv@rudn.university 